\title{
ПОРІВНЯЛЬНИЙ АНАЛІЗ ДОСЛІДЖЕННЯ СТРАТЕГІЙ ПОВЕДІНКИ У ПСИХОТРАВМУЮЧИЙ СИТУАЦЇ̈ ЯК РЕСУРСУ ДЛЯ ПСИХОЛОГІЧНОЇ РЕАБІЛІТАЦІЇ ОСОБИСТОСТІ КОМБАТАНТА
}

УДК: 159.09 .07

\section{Попелюшко Роман Павлович \\ Кандидат психологічних наук, дочент кафедри психології та педагогіки, Хмельницького націо- нального університету, м. Хмельницький (Украӥна)}

\begin{abstract}
Анотація. Метою даної статті було здійснення аналізу результатів діагностичного дослідження стратегій поведінки комбатантів у психотравмуючих ситуащіях, як одного $з$ ресурсів в прочесі їх психологічної реабілітації. Також наголошено, щуо сучасний стан діагностичного дослідження комбатантів вказує на те, щุо при дослідженні, в більшості випадків, виявляються ознаки посттравматичного стресового розладу, стресу, депресії, тривожності, адаптованості та ін., але дуже мало звертають увагу на поведінкові ресурси комбатанта якими він користується при подоланні стресових ситуацій. Актуалізація даного ресурсу комбатанта, дозволить спецііалістам, ефективніше будувати реабілітаційні та адаптаційні заходи з подолання наслідків психотравмуючих ситуаџій, сприятиме забезпеченню збереження психофізичного здоров'я комбатанта.
\end{abstract}

Ключові слова: психологічна реабілітація, канал ресурсу, комбатант, стрес, травматична подія.

Постановка проблеми. На сході нашої держави відбуваються бойові дії у вигляді антитерористичної операції (АТО). Українське сьогодення засвідчує те, що проблема психологічної реабілітації комбатантів, які приймали участь у бойових діях є надзвичайно актуальною проблемою сучасного українського суспільства. Розв'язання проблем пов'язаних 3 психологічною реабілітацією комбатантів $\epsilon$ одним 3 найбільш негайних питань, якому приділяється значна увага в 3МІ та яке виноситься на порядок денний засідань урядових комітетів та громадських організацій.

Діяльність військових в умовах бойових дій характеризується впливом на психіку різних стрес-факторів. Значна тривалість цього впливу, а також травмуючий характер сприяють виникненню патологічних змін у психіці комбатанта, які знижують ефективність його діяльності у бойовій обстановці, при виконанні своїх професійних обов'язків, а також негативно проявляються при повернені до цивільного життя.

Аналіз останніх досліджень і публіка- 
цій, у яких започатковано розв'язання про-

блеми. Різні аспекти вивчення та впровадження основ та механізмів психологічної реабілітації комбатантів, висвітлені у працях таких науковців як: Боченков А. А., Волошин П. В., Доморацький В. А., Караяні О. Г., Ліпатов I. I., Магомед-Емінов М. Ш., Максименко С. Д., Марута Н. О., Неболюва Т. В., Підкоритов В. С., Пушкарьов А. Л., Романовська Д. Д., Тімченко О. В., М. Горовіц, М. Дорон, М. Лаад, Дж. Ротор та ін.

Виділення невиділених раніше частин загальної проблеми. На даний час, все більш гостро постає проблема первинної діагностики поведінкового ресурсу для подальшого його використання у психологічній реабілітації комбатантів, які брали участь у бойових діях, та зазнали бойових психічних чи фізичних травми, і страждають від віддалених наслідків стресогенних впливів. Сучасний стан діагностичного дослідження комбатантів вказує на те, що при дослідженні виявляються ознаки посттравматичного стресового розладу, стресу, депресії, тривожності, адаптованості та ін., але дуже мало звертають увагу на поведінкові ресурси комбатанта якими він користується при подоланні стресових ситуацій. Виявлення цього ресурсу військового, дозволить спеціалістам, ефективніше будувати реабілітаційні та адаптаційні заходи з подолання наслідків психотравмуючих ситуацій, сприятиме забезпеченню збереження психофізичного здоров'я комбатанта.
Мета статті. Здійснити аналіз стратегій поведінки комбатантів у психотравмуючих ситуаціях, як одного з ресурсів в процесі їх психологічної реабілітації.

Завдання статті полягає у здійсненні порівняльного аналізу стратегій поведінки комбатантів у психотравмуючих ситуаціях, до та після їх повернення із зони проведення бойових дій.

Виклад основного матеріалу дослідження 3 повним обгрунтуванням отриманих наукових результатів. Концепція реабілітації комбатантів бере свій початок з розробки її принципів і практичного застосування в Англії та США під час Другої світової війни. Відповідно до сучасних тлумачень цього терміну, реабілітація є системою державних, соціальних, медичних, професійних, педагогічних, психологічних та інших заходів, спрямованих на попередження розвитку патологічних процесів, що призводять до тимчасової або стійкої втрати працездатності, на ефективне і раннє повернення хворих і інвалідів у суспільство і до суспільно-корисної праці. Також, реабілітація являє собою багатогранний процес, в результаті якого у постраждалого формується активне ставлення до порушення його здоров'я і відновлюється позитивне сприйняття життя, сім’ї та суспільства [2].

На сучасному етапі розвитку психологічної науки і практики, психологічна реабілітація комбатанта, включає в себе такі заходи як [4]: 
- своєчасна профілактика i корекція психічних порушень;

- формування у комбатанта свідомої і активної участі у реабілітаційному процесі.

Психологічну реабілітацію комбатанта розглядають як функцію психотерапії та психологічної корекції, що дозволяє говорити про реабілітацію, як про психологічну чи психотерапевтичну інтервенцію [4].

Доктор Мулі Лаад, ізраїльський вчений і практик, у 90-х роках минулого століття, поставив перед собою мету розробити інтегративну модель коду психологічного виживання людини після сильного стресу. Він зацікавився, яким чином люди долають травму, які стратегії вони використовують і чи можна вивести формулу виживання. В результаті багатьох теоретико-практичних досліджень, М. Лаад дійшов висновку, що психологія, зазвичай зосереджена на хворобі, і серйозно недооцінює ресурси людської психіки [1].

Багаторічна дослідницька робота, дозволила створити багатовимірну модель BASIC Ph [1]. Згідно з доктором М. Лаадом, директором Центру профілактики стресу в Кирьят-Шмона, Ізраїль, у кожної людини є 6 основних каналів, кожен 3 який «допомагає» вийти ій 3 кризової ситуації. Зупинимося більш докладніше на кожному з них:

- «B» (базові цінності) - людина 3 домінуючим каналом «В» знайде опору у вірі і духовних цінностях, які допоможуть їй пережити важкі часи напруги та перелому. Тут може бути як релігійна віра, так і політичні переконання, почуття місії (призначення), прагнення до самоздійснення і самовираження;

- «А» (афект) - це тип адаптації, під час якого, людина використовує афективні або емоційні методи: плач, сміх, усний виклад своїх переживань у розмові з ким-небудь, а також можливе промальовування, декламування або прописування своїх емоцій;

- «S» (соціальний) - людина 3 таким типом адаптації знайде підтримку у приналежності до групи, у виконанні завдання, в тому, щоб відігравати якусь роль і бути частиною організації;

- «I» (імагінація, уява) - людина 3 таким типом адаптації використовує свою уяву, щоб замаскувати грубі факти реальності, вона може марити наяву, піддаватися мріям. Вона може уявити собі додаткові рішення проблем рішення, що виходять за межі реалістичних імпровізацій;

- «С» (когнітивне мислення) - це тип адаптації, під час якого людина використовує когнітивні стратегії, які включають в себе, збір інформації, рішення проблем, самоорієнтацію, внутрішній діалог або складання списків дій і переваг;

- «Ph» (фізіологія) - такі люди використовують фізичні, тілесні методи боротьби зі стресом. Ці методи включають релаксацію, десенситизацію, фізичні вправи і фізичну діяльність взагалі [1].

В силу своїх особливостей і умов сере- 
довища військовий має набір стратегій подолання стресової ситуації, кожна $з$ яких звертається до одного з шести каналів. До прикладу, комбатант може вдаватися до емоцій або уяви набагато частіше, ніж до фізичної активності, і навпаки. Тобто, одні канали можу бути добре розвинуті, а інші практично не задіяні - і це зручно доти, поки життєва ситуація не стає тупиковою [3].

Отже, в процесі психологічної реабілітації комбатантів 3 віддаленими наслідками ПТСР, необхідно зосередити увагу, на наявних стратегіях для роботи з більш гострими кризовими ситуаціями, коли військовий втратив усі свої стратегії, заплутався і позбувся землі під ногами.

Сфера проблем комбатантів, 3 якими працює методика, досить широка, але є група проблем, з якими вона найбільш ефективна:

- $\quad$ вікові кризи (криза пов'язана з настанням нових періодів: шлюб, розлучення, народження дитини і т.д.);

- ситуаційні (обумовлені актуальною подією: фізична травма, соматичне захворювання, полон, поїздка чи повернення із зони АТО та ін.);

- проблеми постановки цілей і подолання перешкод на шляху до них (відчуття безцільності, безвиході, непотрібності; пошук свого місця в житті) [3].

Метою нашого експериментального дослідження було виявлення стратегій поведінки комбатантів (які направлялися у зону ан- титерористичної операції (АТО) на сході нашої держави, та згодом прибули на чергову ротацію) у психотравмуючих ситуаціях, як одного з ресурсів в процесі їх подальшої психологічної адаптації та реабілітації. Для реалізації нашої мети було проведено діагностичне дослідження за методикою BASIC Ph (M. Лаад та М. Дорон) [4].

Дослідження проводилось на базі військової частини, польова пошта - 4252, двома етапами. На першому етапі, у лютому 2017 року, діагностувались комбатанти (77 військових) які направлялися у зону АТО, на другому етапі, у травні 2017 року, досліджувалися ті ж підрозділи (59 військових) які прибули на ротацію. Незначна зміна кількості досліджуваних комбатантів, на момент повторної діагностики, пов'язана з закінченням строку служби даними військовими.

На першому етапі діагностичного дослідження, на основі проведеної методики BASIC Ph, ми мали змогу визначити основні канали психологічних ресурсів, кожен $з$ який «допомагає» вийти 3 кризової ситуації комбатантам, які направлялися у зону АТО.

У військових, серед каналів що добре розвинуті, ми спостерігали наступні результати: канал «В» (базові цінності) спостерігався у 8 (10\%) військових, канал «А» (афект) не був виявлений жодним комбатантом, канал «S» (соціальний) простежувався у 5 (7\%) осіб, канал «I» (імагінація, уява) був констатований у 5 (7\%) військових, канал «С» (когнітивне 
мислення) виявився аж у 59 (76\%) осіб, каналу «Рh» (фізіологія) у комбатантів не виявлеHO.

Отримані результати попереднього дослідження, добре розвинутих каналів психологічного ресурсу комбатантів, представлено на рис. 1.

При попередньому дослідженні, серед каналів що потребують найбільшого розвитку у комбатантів, нами були констатовані такі результати: канал «В» (базові цінності) виявився у 8 (10\%) осіб, канал «А» (афект) спостерігався у 36 (48 \%) військових, канал «S» (соціальний) простежувався у 8 (10\%) комбатантів, канал «I» (імагінація, уява) спостерігався у 15 (19 \%) осіб, канал «С» (когнітивне мислення) у комбатантів ви- явило не було, канал «Рh» (фізіологія) виявився у 10 (13\%) осіб.

Отримані результати попереднього дослідження, каналів психологічного ресурсу які потребують розвитку у комбатантів представлено на рис. 2.

Порівняльні результати попереднього дослідження стратегій поведінки комбатантів у психотравмуючих ситуаціях представлені у таблиці 1.

Отримані результати попереднього дослідження, дали нам змогу констатувати той факт, що у більшої частини військових, які відправлялися у зону АТО, найкраще розвинутий канал ресурсності «С». Це свідчить про те, що при подоланні кризових ситуацій, яких буде багато під час бойових дій на сході краї-

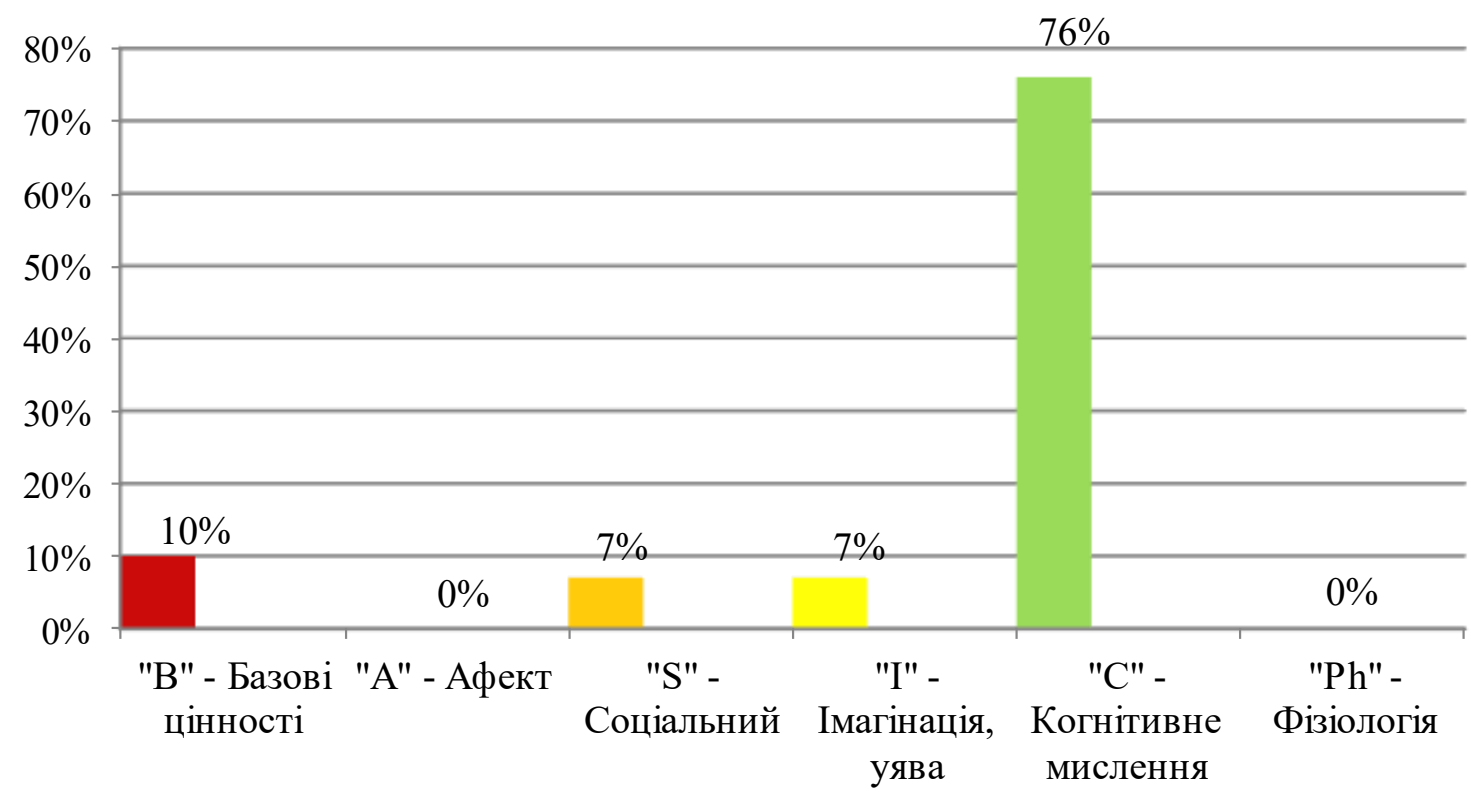

Рис. 1. Результати переднього дослідження комбатантів за методикою BASIC Ph (добре розвинуті канали психологічного ресурсу) 


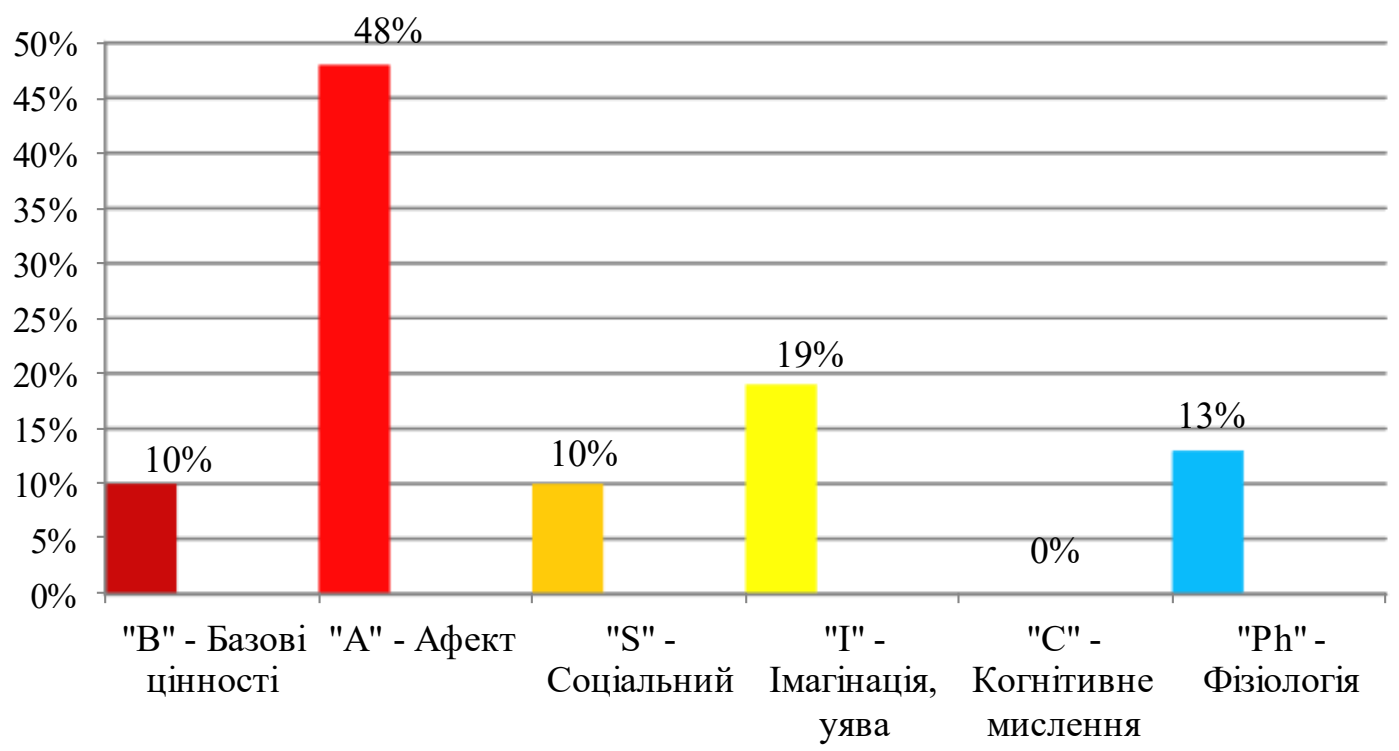

Рис. 2. Результати попереднього дослідження комбатантів за методикою BASIC Ph (канали психологічного ресурсу які потребують розвитку)

ни, психологічним ресурсом для комбатантів будуть являтися їх переконання, розсудливість, реальність, логіка, планування, навчання, інформація, порядок їх пріоритетів та аль- чають в себе, збір інформації, рішення проблем, самоорієнтацію, внутрішній діалог або складання списків дій і переваг. Це в свою чергу, призведе до більш адекватного реагу-

Таблиия 1

Результати попереднього дослідження комбатантів за методикою BASIC Ph

\begin{tabular}{|c|c|c|c|c|}
\hline \multirow{2}{*}{$\begin{array}{l}\text { Канали психологічного ресу- } \\
\text { рсу }\end{array}$} & \multicolumn{2}{|c|}{ Найбільш розвинуті } & \multicolumn{2}{|c|}{ Потребують розвитку } \\
\hline & Кількість досл. & $\%$ & Кількість досл. & $\%$ \\
\hline «В»- Базові цінності & 8 & 10 & 8 & 10 \\
\hline «А»-Афект & 0 & 0 & 36 & 48 \\
\hline «S»- Соціальний & 5 & 7 & 8 & 10 \\
\hline «I»- Імагінація, уява & 5 & 7 & 15 & 19 \\
\hline «С»- Когнітивне мислення & 59 & 76 & 0 & 0 \\
\hline «Ph»- Фізіологія & 0 & 0 & 10 & 13 \\
\hline
\end{tabular}

тернатив. Такий канал психологічного ресурсу та адаптації комбатантів, буде направлений на використання когнітивних стратегії, які вклю- вання на психотравмуючі ситуації і дозволить зберегти психофізичне здоров'я комбатанта, під час перебування у зоні АТО [3]. 
Також, під час попереднього дослідження, були виявлені канали які потребують найбільшого розвитку. У великої кількості військових, спостерігається тенденція до вибору каналу ресурсності «А». Даний вибір свідчить про те, що при подоланні кризових психотравмуючих ситуацій, психологічним ресурсом для комбатантів не будуть являтися їх емоційний обмін почуттями, дзвінки іншим, написання віршів чи прози, малювання, пряме або непряме вираження їх емоцій. Даний канал психологічного ресурсу та адаптації комбатантів, на буде використовувати такі афективні або емоційні методи як: плач, сміх, виклад своїх переживань у розмові з ким-небудь, а також можливе промальовування, декламування або прописування своїх емоцій. Це в свою чергу, може призвести до загрубіння емоційної сфери, порушення довірливої комунікації серед комбатантів та ускладнити подальшу психокорекційну чи реадаптаційну роботу фахівців з подолання наслідків посттравматичного стресового розладу та інших психосоматичних симптомів [3].

На основі повторно проведеної методики BASIC Ph, було виявлено найбільш розвинуті канали психологічного ресурсу та ті канали які потребували найбільшого розвитку. У комбатантів, серед каналів що добре розвинуті, ми спостерігали наступні результати: канал «В» (базові цінності) виявився у 13 (22\%) осіб, канал «А» (афект) не констатовано у жодної особи, канал «S» (соціальний) простежувався у 3 (5\%) військових, канал «І» (імагінація, уява) спостерігався у 1 (2\%) особи; канал «С» (когнітивне мислення) виявився у 41

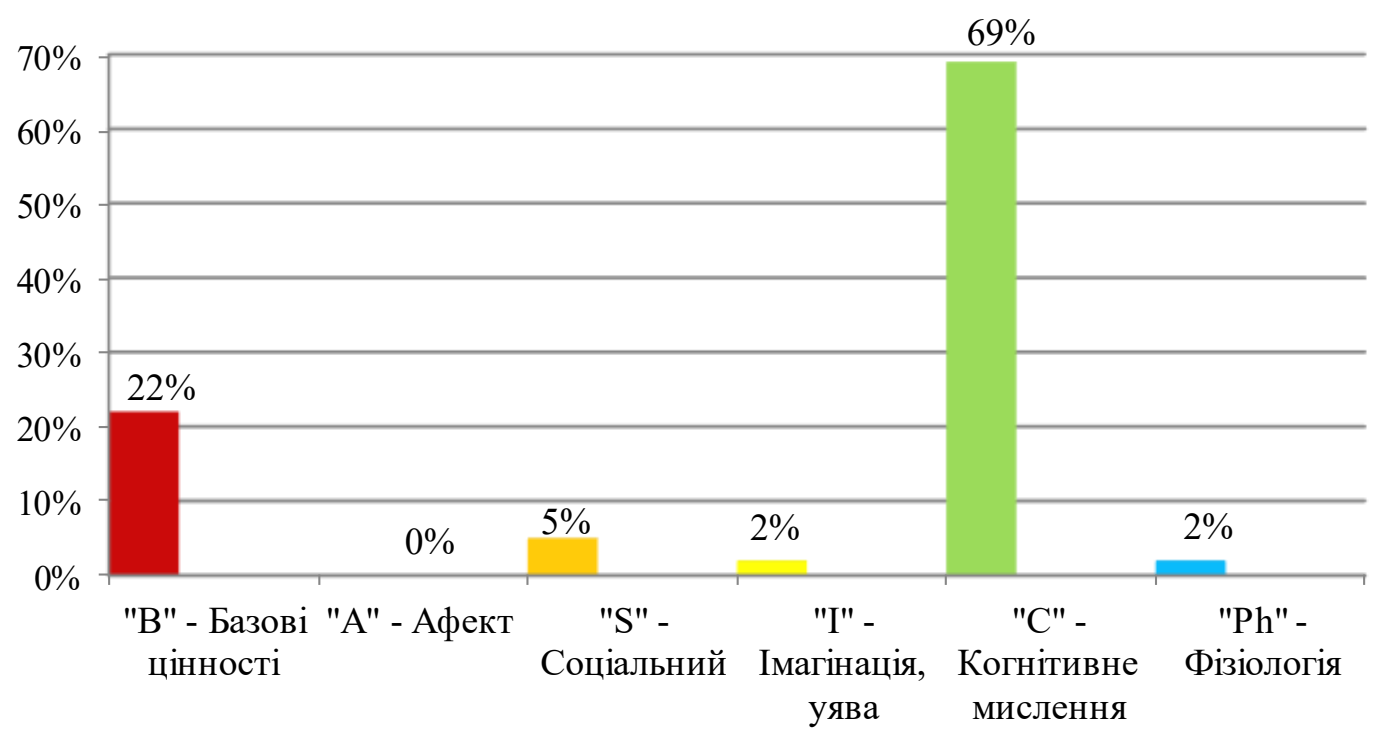

Рис. 3. Результати повторного дослідження комбатантів за методикою BASIC Ph (добре розвинуті канали психологічного ресурсу) 
(69\%) комбатанта, канал « $\mathrm{Ph} »$ (фізіологія) спостерігався у 1 (2\%) особи.

Отримані результати повторного дослідження, добре розвинутих каналів психологічного ресурсу комбатантів, представлено на рис. 3.

Також, під час повторного дослідження, було виявлено канали, що потребують найбільшого розвитку у комбатантів. В результаті чого, ми отримали наступні результати: канал «В» (базові цінності) виявився у 4 (7\%) військових, канал «А» (афект) спостерігався у 32 (55\%) осіб, канал « $\mathrm{S} »$ (соціальний) констатований у 9 (15\%) осіб, канал «I» (імагінація, уява) продіагностований у 8 (13\%) осіб, канал «С» (когнітивне мислення) серед комбатантів не виявила жодна особа, канал
«Ph» (фізіологія) спостерігався у 6 (10\%) осіб.

Отримані результати повторного дослідження, каналів психологічного ресурсу які потребують розвитку у комбатантів представлено на рис. 4.

Порівняльні результати повторного дослідження стратегій поведінки комбатантів у психотравмуючих ситуаціях представлені у таблиці 2.

Виходячи з отриманих результатів попереднього та повторного досліджень, ми можемо констатувати той факт, що у більшої частини комбатантів, які вирушали та повернулися із зони АТО, найкраще розвинутий канал ресурсності «С». Даний результат свідчить про те, що при подоланні кризових ситуацій, яких було достатньо під час несення ними

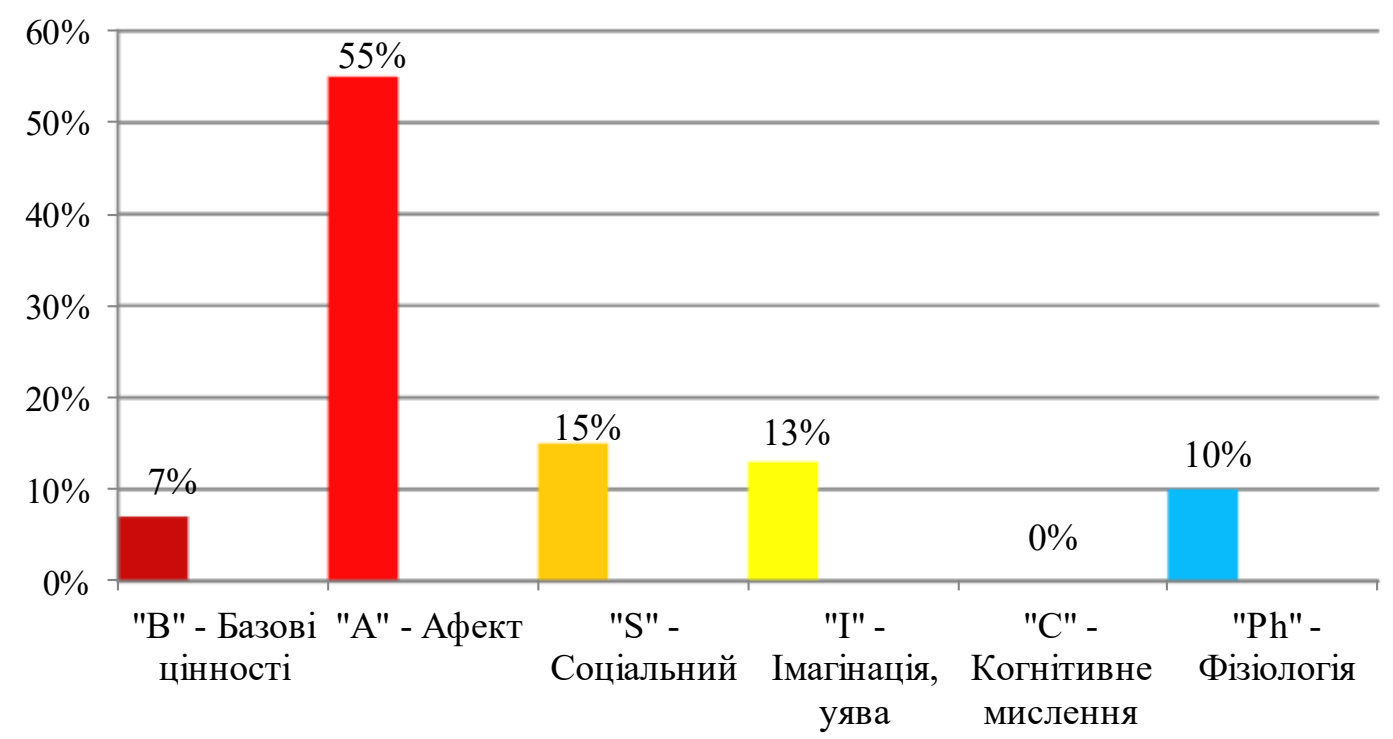

Рис. 4. Результати повторного дослідження комбатантів за методикою BASIC Ph (канали психологічного ресурсу які потребують розвитку) 
служби на сході країни, психологічним ресурсом для комбатантів були їх переконання, розсудливість, реальність, логіка, планування, інформація. Такий канал психологічного ресу-
Дані канали, дозволили комбатантам, більш адекватно реагувати на психотравмуючі ситуації і зберегти власне психічне та фізичне здоров'я, під час перебування у зоні АТО.

Таблиия 2

\section{Результати повторного дослідження комбатантів за методикою BASIC Ph після повернення із зони АТО}

\begin{tabular}{|l|l|l|l|l|}
\hline \multirow{2}{*}{$\begin{array}{l}\text { Канали психологічного ресур- } \\
\text { су }\end{array}$} & Найбільш розвинуті & \multicolumn{2}{|l|}{ Потребують розвиту } \\
\cline { 2 - 5 } & Кількість досл. & $\%$ & Кількість досл. & $\%$ \\
\hline «В»- Базові цінності & 13 & 22 & 4 & 7 \\
\hline «А»-Афект & 0 & 0 & 32 & 55 \\
\hline «S»- Соціальний & 3 & 5 & 9 & 15 \\
\hline «І»- Імагінація, уява & 1 & 2 & 8 & 13 \\
\hline «С»- Когнітивне мислення & 41 & 69 & 0 & 0 \\
\hline «Рһ»- Фізіологія & 1 & 2 & 6 & 10 \\
\hline
\end{tabular}

рсу та адаптації комбатантів, був направлений на використання когнітивних стратегії, які включають в себе, збір інформації, рішення проблем, самоорієнтацію, внутрішній діалог або складання списків дій і переваг.

Необхідно зазначити, що при повторному досліджені, канал «В» виявили близько четвертої частини всіх комбатантів, що не спостерігалося при попередньому діагностуванні. Даний результат свідчить про те, що при подоланні кризових ситуацій, психологічним ресурсом для комбатантів були їх переконання, цінності, надія, самооцінка, сенс життя, погляди і вірування, релігія, почуття спільності та приналежності до однієї великої групи побратимів, вираз подяки і визнання цінності інших колег, зміцнення військового партнерства.
Під час попереднього та повторного дослідження було виявлено, що серед каналів які потребують найбільшого розвитку, у великої кількості комбатантів, спостерігається тенденція до вибору каналу «А». Необхідно також зазначити, що даний показник збільшився з 48\% при первинному дослідженні, до 55\% після повернення комбатантів із зони АТО. Даний результат вказує на те, що при подоланні кризових ситуацій, психологічним ресурсом для комбатантів не будуть являтися їх обмін почуттями, дзвінки іншим, пряме або непряме вираження їх емоцій. Цей канал психологічного ресурсу та адаптації комбатантів, на буде використовувати такі афективні методи як: плач, сміх, виклад своїх переживань у розмові. Це в свою чергу, може призвести до ригідності та гіпотимії емоційної сфери, пору- 
шенню ефективної комунікації серед комбатантів та ускладнити подальшу реабілітаційну чи адаптаційну роботу психологів та інших фахівців $з$ подолання наслідків посттравматичного стресового розладу чи інших психосоматичних симптомів.

Порівняльні результати дослідження стратегій поведінки комбатантів у психотравмуючих ситуаціях, за методикою BASIC Ph, до та після повернення із зони АТО, представлені у таблиці 3.

Висновки 3 даного дослідження. Аналіз дослідження, стратегій поведінки комбатантів у психотравмуючих ситуаціях, як ресурсу в процесі психологічної реабілітації, дозволив нам зробити такий висновок, що у військових, які вирушали та повернулись із зони АТО, краще розвинуті такі канали як «С» (когнітивне мислення) та «В» (базові цінності). Ці канали були направлені на викорис- бойових проблем, самоорієнтацію, складання списків власних дій (в тій чи іншій екстремальній ситуації). Також комбатанти знаходили опору у вірі, духовних цінностях, власних переконаннях, почутті місії (захист власної держави), прагненні до самоздійснення та самовираження, це допомагало їм пережити важкі часи та перелому.

Задіяння даних каналів ресурсу, у реабілітаційному та адаптаційному процесах, на нашу думу, може призвести до більш адекватного реагування на травматичні бойові та не бойові ситуації, стійкості та вмотивованості патріотичних настроїв та дозволить зберегти на адекватному рівні боєздатність та психофізичне здоров'я комбатантів.

Також при попередньому дослідженні було виявило, що у комбатантів недостатньо розвинуті такі канали ресурсу як «А» (афект), «I» (імагінація, уява) та «Ph» (фізіологія). Таблиия 3

Порівняння результатів дослідження комбатантів за методикою BASIC Ph до та після повернення із зони АТО

\begin{tabular}{|c|c|c|c|c|}
\hline \multirow[b]{2}{*}{$\begin{array}{l}\text { Канали психологічного ре- } \\
\text { сурсу }\end{array}$} & \multicolumn{2}{|c|}{ Попереднс дослідження } & \multicolumn{2}{|c|}{ Повторне дослідження } \\
\hline & $\begin{array}{l}\text { Найбільш } \\
\text { розвинуті }\end{array}$ & $\begin{array}{l}\text { Потребують } \\
\text { розвитку }\end{array}$ & $\begin{array}{l}\text { Найбільш } \\
\text { розвинуті }\end{array}$ & $\begin{array}{l}\text { Потребують } \\
\text { розвитку }\end{array}$ \\
\hline «В»- Базові цінності & $10 \%$ & $10 \%$ & $22 \%$ & $7 \%$ \\
\hline «А»-Афект & $0 \%$ & $48 \%$ & $0 \%$ & $55 \%$ \\
\hline «S»- Соціальний & $7 \%$ & $10 \%$ & $5 \%$ & $15 \%$ \\
\hline «I»- Імагінація, уява & $7 \%$ & $19 \%$ & $2 \%$ & $13 \%$ \\
\hline «С»- Когнітивне мислення & $76 \%$ & $0 \%$ & $69 \%$ & $0 \%$ \\
\hline «Рh»- Фізіологія & $0 \%$ & $13 \%$ & $2 \%$ & $10 \%$ \\
\hline
\end{tabular}

тання таких когнітивних стратегії, як збір опе- Цими каналами будуть мінімально чи взагалі ративної інформації, рішення бойових та не не будуть використовуватися (при подоланні 
стресових травмуючих ситуації) плач (втрата побратима), сміх, виклад своїх переживань у розмові з психологом чи командиром підрозділу, власна уява (щоб скрити екстремальні факти бойової обстановки), тілесні методи боротьби зі стресом.

Натомість при повторному досліджені, комбатантів які повернулися із зони АТО, каналами що недостатньо розвинуті, виявились «A» (афект), «S» (соціальний), «I» (імагінація, уява). Це свідчить про те, що до попередніх обмежень використання психологічного ресурсу комбатантами, при подоланні психотравмуючих впливів, додалися ще, обмеженість у соціальному спілкуванні з друзями, сім'єю та іншими важливими людьми, взаємній допомозі і підтримці, почутті власної соціальної цінності.

Не використання даних каналів ресурсу на належному рівні, може призвести до негативного неадекватного реагування на травмуючі ситуації та бойову обстановку, зниженню особистісної стійкості та вмотивованості. Також буде сприяти незадовільній адаптації та реабілітації військових, та виникненню проблем психологічного характеру, по підтриманню у них та членів їх сімей належного морально-психологічного стану.

\section{Перспективи подальших розвідок у} даному напрямі. Проблема, яка порушена, $\epsilon$ актуальною та важливою для подальшого вивчення та впровадження у практику психологічної реабілітації комбатантів. Перспективу подальших досліджень ми вбачаємо у дослідженні та впровадженні у психологічну практику діагностичного дослідження комбатантів, методики BASIC $\mathrm{Ph}$, це в свою чергу забезпечить розширення перспектив збереження психофізичного здоров'я комбатантів, профілактику після стресових реакцій, побудову ефективних реабілітаційних процесів.

\section{Перелік використаних джерел:}

1. Лаад М. Как справиться с кризисом или бедствием (Шаг за шагом): Теория, практика и способы вмешательства / М. Лаад, Э. Хадоми. - Израиль: Центр предупреждения стресса (CSPC) [Электронный ресурс]. Режим доступа: http://www.silk-highway.org/ru/ stepGuide.aspx. - Дата доступа: 18.08.2010.

2. Магомед-Эминов М.Ш. Новые аспекты психотерапии посттравматического стресса. Методические рекомендации / М.Ш. Магомед-Эминов, Г.И. Кадук, А.Т. Филатов, О.Г. Квасова. - М.: АНОУМО «Инсайт», 2004. $200 \mathrm{c}$.

3. Попелюшко Р.П. Дослідження стратегій поведінки у психотравмуючий ситуації як ресурсу для психологічної реабілітації особистості комбатанта / Р.П. Попелюшко // Науковий вісник Херсонського державного університету. Серія: Психологічні науки. - 2017. - Вип. 1, т. 1. - С. 104-108.

4. Черепанова И.В., Черепанов О.А. Основы психологической помощи: курс лекций / И.В. Черепанова, О.А. Черепанов. - Могилев: МГУ им. А.А. Кулешова, 2014. $-304 \mathrm{c}$.

\section{References (Transliteration):}

1. Laad M. Kak spravitsya s krizisom ili bedstviem (Shag za shagom): Teoriya, praktika i sposobyi vmeshatelstva / M. Laad, E. Hadomi. - Izrail: Tsentr preduprezhdeniya 
stressa (SSPC) [Elektronnyiy resurs]. - Rezhim dostupa: http://www.silk-highway.org/ru/stepGuide.aspx. - Data dostupa: 18.08.2010.

2. Magomed-Eminov M.Sh. Novyie aspektyi psihoterapii posttravmaticheskogo stressa. Metodicheskie rekomendatsii / M.Sh. Magomed-Eminov, G.I. Kaduk, A.T. Filatov, O.G. Kvasova. - M.: ANOUMO «Insayt», 2004. $200 \mathrm{~s}$.

3. Popelyushko R.P. Doslidzhennya strategiy povedinki u psihotravmuyuchiy situatsiyi yak resursu dlya psihologichnoyi reabilitatsiyi osobistosti kombatanta / R.P. Popelyushko // Naukoviy visnik Hersonskogo derzhavnogo universitetu. Seriya: Psihologichni nauki. - 2017. - Vip. 1, t. 1. - S. 104-108.

4. Cherepanova I.V., Cherepanov O.A. Osnovyi psihologicheskoy pomoschi: kurs lektsiy / I.V. Cherepanova, O.A. Cherepanov. - Mogilev: MGU im. A.A. Kuleshova, 2014. - 304 s.

\section{Popelushko Roman}

Ph.D, Prof., Assistant Professor of the Department of Psychology and Pedagogy, Khmelnitsky National University, Khmelnitsky (Ukraine)

\section{COMPARATIVE ANALYSIS OF RESEARCH ON BEHAVIOR STRATEGIES IN THE TRAUMATIC SITUATION AS A RESOURCE FOR PSYCHOLOGICAL REHABILITATION OF COMBATANTS PERSONALITY}

\footnotetext{
ABSTRACT

The purpose of this article was to analyze the results of the diagnostic study behavioral strategies combatants in stressful situations, as one of the resources in the process of their psychological rehabilitation.

It is also noted that the current state of the diagnostic study of combatants points out that the
}

study revealed signs of post-traumatic stress disorder, stress, depression, anxiety, adaptability and others, but very few pay attention to behavioral resources a combatant that he uses to overcome stressful situations.

Actualization of this resource of the combatant will allow the specialists, to build rehabilitation and adaptation measures more effectively to overcome the consequences of traumatic situations, will contribute to maintaining the physical and psychological health of the combatant.

Key words: psychological rehabilitation, channel of the resource, combatant, stress, traumatic event.

\section{Попелюшко Роман Павлович}

Кандидат психологических наук, дочент кафедры психологии и педагогики, Хмельницкого национального университета, г. Хмельниџкий (Украина)

\section{СРАВНИТЕЛЬНЫЙ АНАЛИЗ ИССЛЕДОВАНИЯ СТРАТЕГИЙ ПОВЕДЕНИЯ В ПСИХОТРАВМИРУЮЩЕЙ СИТУАЦИИ КАК РЕСУРСА ДЛЯ РЕАБИЛИТАЦИИ ЛИЧНОСТИ КОМБАТАНТОВ}

Аннотация. Целью данной статьи было осуществление анализа результатов диагностического исследования стратегий поведения комбатантов в психотравмирующих ситуациях, как одного из ресурсов в процессе их психологической реабилитации.

Также отмечено, что современное состояние диагностического исследования комбатантов указывает на то, что при исследова- 
нии выявляются признаки посттравматического стрессового расстройства, стресса, депрессии, тревожности, адаптированности и др., но очень мало обращают внимание на поведенческие ресурсы комбатанта которыми он пользуется при преодолении стрессовых ситуаций. Актуализация данного ресурса комбатанта, позволит специалистам, эффективнее строить реабилитационные и адаптационные меры по преодолению последствий психотравмирующих ситуаций, будет способствовать обеспечению сохранности психофизического здоровья комбатанта.

Ключевые слова: психологическая реабилитация, канал ресурса, комбатант, стресс, травматическое событие. 